\title{
A nemzetközi pénzügyi beszómolási standardok (IFRS) alapján teljesített statisztikai adatszolgáltatás módszertanának háttere és topasztalatai
}

\section{Madarasiné Szirmai} Andrea,

a Budapesti Gazdasági Egyetem egyetemi docense

E-mail: szirmai.andrea@uni-bge.hu

\section{Szöllösiné Szép Adrienn,}

a Központi Statisztikai Hivatal főosztályvezetője

E-mail: adrienn.szep@ksh.hu
Magyarországon az IFRS egyedi beszámolási célú alkalmazásának bevezetéséhez kapcsolódó 2015. évi CLXXVIII. törvény (továbbiakban IFRS-törvény) 2016. január 1-jétöl hatályos.

Az IFRS-törvényen túl számos olyan mikro- (vállalati) és makroszintü folyamat kidolgozása vált szükségessé, amelyek e nemzetközi standardok használatát valóban sikeressé teszik. Ezek közül az egyik makroszintü feladat a statisztikai adatszolgáltatások újragondolása.

Jelen tanulmány keretében a szerzők azt mutatják be, hogy az IFRS-törvény hatására a KSH mely adatszolgáltatásainak elemzése és módosítása vált szükségessé abból adódóan, hogy a magyar szabályoktól eltérő, IFRS szerinti megjelenítési és értékelési szabályok közül melyek bírnak makrogazdasági jelentőséggel, befolyásolva a $\mathrm{KSH}$ által számított makrogazdasági mutatók értékét.

A tanulmány a statisztikai adatszolgáltatásokat tekintve összegzi azokat a folyamatokat és eredményeiket, amelyeket a KSH, a NAV és az MNB munkatársai 2015 vége óta közösen hajtanak végre annak érdekében, hogy a jogi szabályozásoknak megfelelő és jól értelmezhető adatszolgáltatási megoldások álljanak rendelkezésre az IFRS rendszerére átálló vállalkozások számára.

TÁRGYSZÓ:

Nemzetközi pénzügyi beszámolási standardok (IFRS).

IFRS egyedi alkalmazása.

Statisztikai adatszolgáltatás.

DOI: 10.20311/stat2018.05.hu0489 
Az IFRS (International Financial Reporting Standards - nemzetközi pénzügyi beszámolási standardok) kidolgozása 1973-ban kezdödött. Megalkotásának elsődleges célja az volt, hogy egységesítse az országok pénzügyikimutatás-készítésének (értékelési) elveit, módszereit, eljárásait, illetve egyértelmüsítse az azokkal kapcsolatos fogalmakat. A standardalkotók érthető, magas színvonalú, jól használható, globális számviteli standardsorozatot hoztak létre, és igyekeztek elősegíteni alkalmazását.

Az Európai Unióban voltak régebben törekvések egységes európai számviteli standardok kidolgozására, de 1995-ben felhagytak ezzel a szándékkal, és elfogadták az IFRS-szel foglalkozó bizottság (IASC [International Accounting Standards Committee - Nemzetközi Számviteli Standard Bizottság], 2001-től IASB [International Accounting Standards Board - Nemzetközi Számviteli Standard Testület]) által alkotott standardokat. Az Európai Unió a tőzsdéin jegyzett társaságok részére 2005. január 1-jétől tette kötelezővé az IFRS-en alapuló konszolidált pénzügyi kimutatások összeállítását.

\section{Az IFRS alkalmazása a világ országaiban}

Napjainkban az IFRS-t ${ }^{1}$ széles körben alkalmazzák, miközben folyamatosan zajlik aktualizálása és összehangolása más irányadó nemzetközi szervezetek szabályaival, állásfoglalásaival.

Az IFRS szervezete által végzett felmérés ${ }^{2}$ alapján a vizsgált 150 országból 142 fejezte ki az IFRS iránti elkötelezettségét. Százhuszonhat országban követelik meg a standardok használatát valamennyi vagy a legtöbb, nemzeti jog szerint működő és nyilvános elszámolásra kötelezett társaság esetén (amelyekhez elsődlegesen a tőzsdén jegyzett vállalatok és a pénzügyi intézmények tartoznak), de a többiben is (jellemzően) lehetővé teszik az alkalmazásukat. Kilenc országban nem müködik tőzsde,

${ }^{1}$ Az IFRS rendszere a következőket öleli fel: 1 . az IFRS standardalkotó szervezete, az IASB által kiadott IFRS-t; 2. az IASB elődjének, az IASC IAS-ét (international accounting standards - nemzetközi számviteli standardok); 3. az IFRS és az IAS IFRIC-e (International Financial Reporting Interpretations Committee - Nemzetközi Pénzügyi Beszámolási Standardok Értelmezési Bizottsága)által kidolgozott és az IASB által közzétételre jóváhagyott értelmezéseket; 4. az IFRIC jogelődjeként 2001 decemberéig müködő SIC (Standing Interpretation Committee - Értelmezési Állandó Bizottság) IASB által közzétételre jóváhagyott értelmezéseit; valamint 5. a szabályok összhangját megalapozó elvi keretet (ami nem kötelező előírás, de ismerete elengedhetetlen a standardok értelmezéséhez és alkalmazásához).

${ }^{2}$ http://www.ifrs.org/use-around-the-world/use-of-ifrs-standards-by-jurisdiction/\#analysis 
viszont minden hitelintézet számára kötelezők e standardok, míg 6 országban a tőzsdén jegyzett hitelintézeteknek nem, de a tôzsdén jegyzett vállalkozások számára elöírták, hogy pénzügyi kimutatásaikat az IFRS alapján készítsék. Az európai országok 98, az afrikaiak 80, a közel-keletiek 92, az amerikaiak 73, az ázsiai-óceániaiak 74 százaléka követeli meg, hogy a nemzeti jog szerint múködő és nyilvános elszámolási kötelemmel bíró társaságok az IFRS-t alkalmazzák.

A 126 ország legtöbbje a tőzsdén nem jegyzett vállalkozások számára (mely körhöz általában pénzügyi intézmények és nagyvállalatok tartoznak) kötelezővé vagy lehetővé teszi (megközelítőleg 60 százalékuk írja elő) e standardok használatát.

A vizsgált 150 ország 2015. évi GDP- (gross domestic product - bruttó hazai termék) adatainak elemzése alapján megállapítható, hogy a nemzeti jog szerint müködő, nyilvános elszámolásra kötelezett társaságok az IFRS-t előíró vagy lehetővé tevő országok GDP-jének 55 százalékát teszik ki.

A következőkben az IFRS alkalmazásának kérdését vállalkozásszinten vizsgáljuk. A tőzsdéket összefogó két legnagyobb globális szervezet, a WFE (World Federation of Exchanges - Tőzsdék Világszövetsége) és a FEAS (Federation of European and Asian Stock Exchanges - Európai és Ázsiai Tőzsdék Szövetsége) 2015. év végi adatai alapján összesen 85 tőzsdét és 50356 jegyzett társaságot tartanak nyilván. Az elöbbieken jegyzett, körülbelül 48 000, nemzeti jog szerinti müködő társaságból világszerte több mint 25 ezer alkalmazza az IFRS-t, ugyanakkor a Kínában, az Indiában, a Japánban és az Egyesült Államokban jegyzettek közül egy sem.

Az IFRS-ről pozitív visszajelzéseket és értékeléseket adnak az országok. 2015ben az Európai Bizottság egy kiadványban publikálta ${ }^{3}$ az elmúlt tíz év ezzel kapcsolatos tapasztalatait, melynek legföbb üzenete az volt, hogy a standardok által sikeresen létrejött a tőkepiacok közös számviteli nyelve. A társaságok szintén pozitívan nyilatkoztak/nyilatkoznak, véleményük szerint az IFRS alkalmazásának nagyobb haszna volt/van, mint költsége. A befektetők az átláthatóság és a pénzügyi kimutatások összehasonlíthatósága miatt támogatják az IFRS-t. Közel száz akadémiai tanulmány összehasonlítása alapján levonhatjuk azt a következtetést, hogy a legtöbb írás szerzőjének véleménye szerint a standardok alkalmazása javította a tőkepiacok müködésének hatékonyságát, és elősegítette a határokon átívelö befektetéseket.

A témát a világ országai és a gazdálkodóegységek szerint vizsgálva megállapítható, hogy az IFRS világszerte elterjedt, és a legtöbb országban kötelezö jelleggel alkalmazandó a nyilvános elszámolásra kötelezett gazdálkodóegységek egyedi és konszolidált pénzügyi kimutatásaiban, de a nyilvános elszámolásra nem kötelezett gazdálkodóegységeket tekintve ugyancsak jelentős elörelépések figyelhetők meg e téren. Az utóbbi társaságok esetén azonban, amellett, hogy a nemzeti jogszabályi keretek lehetővé teszik, a szervezetek döntésének függvénye az IFRS-re való áttérés. Nyil-

\footnotetext{
${ }^{3}$ https://www.iasplus.com/en/news/2015/06/ias-regulation
} 
vánvaló, hogy minél több nagyvállalatnak minősülő gazdálkodóegység alkalmazza e standardokat az egyedi pénzügyi kimutatások szintjén, azok annál meghatározóbbá válnak a nemzetgazdasági mutatók, így a GDP számításában. Ezért elengedhetetlen, hogy a szakemberek tisztában legyenek a nemzetgazdasági statisztikai adatszolgáltatások során bekért adatokra vonatkozó IFRS-besorolási és -értékelési tényezőkkel, amelyek módosíthatják a statisztikai adatok értékét, valamint azzal, hogy e hatások időbeliségüket tekintve két vagy több év vonatkozásában visszafordulnak-e, vagy véglegesen beépülnek a vagyonba és/vagy eredménybe.

\section{Az IFRS alkalmazásának magyarországi jogszabályi keretei}

Az Európai Parlament és a Tanács nemzetközi számviteli standardok alkalmazásáról szóló 1606/2002/EK rendelete (2002. július 19.) utat nyitott az IFRS széles körü alkalmazása felé azzal, hogy előírta, az Európai Unió tőzsdéin jegyzett, konszolidált pénzügyi kimutatásokat készítő vállalkozásoknak 2005-től kötelező az IFRS szabályaival összhangban készíteniük a pénzügyi kimutatásaikat.

A rendelet azonban nem terjedt ki az IFRS egyedi pénzügyi kimutatásokban való alkalmazására. Az utóbbi kérdést Magyarországon az 1387/2015. (VI. 12.) Korm. határozat rendezte, amelyben az ország kormánya elkötelezte magát e standardok egyedi beszámolási célú bevezetése mellett. Az Országgyülés, a kormányhatározat hatálybalépését követő hosszú előkészítő és egyeztető munka eredményeként, 2015. november 17-én fogadta el az IFRS-re történő áttérés jogszabályi feltételeit meghatározó törvényjavaslatot. Az IFRS egyedi beszámolási célokra történő hazai alkalmazásának bevezetéséhez kapcsolódó, valamint egyes pénzügyi tárgyú törvények módosításáról szóló 2015. évi CLXXVIII. törvényt 2015. november 26-án hirdették ki, és 2016. január 1-jén lépett hatályba.

Az IFRS egyedi beszámolási célú alkalmazásának lehetőségeit és kötelezettségeit a 2000. évi C. törvény a számvitelről (a továbbiakban Szt.) 9/A.§-a foglalja össze.

Nem alkalmazhatják az IFRS-t egyedi beszámolási célra az állami és az önkormányzati vagyonkezelést végző vállalkozók, a nonprofit gazdasági társaságok, a biztosítási tevékenységről szóló törvény szerinti kölcsönös biztosító egyesületek, valamint a nyugdíj-, az egészség- és az önsegélyező pénztárak. 
Az IFRS magyarországi alkalmazása egyedi pénzügyi kimutatásokra

\begin{tabular}{|c|c|}
\hline Év/érvény & Érintett szektor/gazdálkodóegység \\
\hline 2016/válaszható & $\begin{array}{l}\text { - az MNB (Magyar Nemzeti Bank) által felügyelt intézmények kivételével az a vállalko- } \\
\text { zó, akinek értékpapírjait az Európai Gazdasági Térség bármely államának szabályozott } \\
\text { piacán forgalmazzák } \\
\text { - az a vállalkozó, akinek közvetlen vagy közvetett anyavállalata az összevont (konszoli- } \\
\text { dált) éves beszámolóját az IFRS szerint készíti el }\end{array}$ \\
\hline 2017/kötelező & $\begin{array}{l}\text { - az MNB által felügyelt intézmények kivételével az a vállalkozó, akinek értékpapírjait az } \\
\text { Európai Gazdasági Térség bármely államának szabályozott piacán forgalmazzák }\end{array}$ \\
\hline 2017/választható & $\begin{array}{l}\text { - biztosítótársaság } \\
\text { - a pénzügyi közvetítőrendszer felügyeletével kapcsolatos feladatkörében eljáró MNB } \\
\text { felügyelete alá tartozó pénzügyi vállalkozás, pénzforgalmi intézmény, elektronikus- } \\
\text { pénz-kibocsátó intézmény, befektetési vállalkozás, központi értéktár, központi szerződő } \\
\text { fél, tőzsde, foglalkoztatói nyugdíjszolgáltató } \\
\text { - hitelintézet, továbbá a hitelintézettel egyenértékü prudenciális szabályozásnak megfelelö } \\
\text { pénzügyi vállalkozás } \\
\text { - az IFRS-ek szerint készített konszolidált pénzügyi kimutatásokba anyavállalati döntés } \\
\text { alapján bevont pénzpiaci közvetítő és biztosításközvetítő, valamint a kollektív befekte- } \\
\text { tési formákról és kezelöikről, illetve az egyes pénzügyi tárgyú törvények módosításáról } \\
\text { szóló törvény hatálya alá tartozó alap és alapkezelő } \\
\text { - külföldi székhelyủ vállalkozás magyarországi fióktelepe } \\
\text { - árbevétel- és létszámkritériumok alapján könyvvizsgálati kötelezettség alá eső társaság }\end{array}$ \\
\hline 2018/kötelező & $\begin{array}{l}\text { - hitelintézet és az azzal egyenértékủ prudenciális szabályozás alá eső pénzügyi vállalko- } \\
\text { zás }\end{array}$ \\
\hline 2019/kötelező & $\begin{array}{l}\text { - szövetkezeti hitelintézet és a szövetkezeti hitelintézetek integrációjában részt vevö } \\
\text { egyéb hitelintézet }\end{array}$ \\
\hline
\end{tabular}

Forrás: 2000. évi C. törvény a számvitelröl.

2016-ben 12, 2017-ben 135 vállalkozás tért át az IFRS-re. Az IFRS-t alkalmazó és az összes társas vállalkozás száma ${ }^{4} 2017$. év elején, ágazati bontásban a 2. táblázat szerint alakult.

${ }^{4}$ A 2. táblázatban az IFRS-t alkalmazó vállalkozások száma a társasági adóbevallást készítő vállalkozásokat fedi le a NAV (Nemzeti Adó- és Vámhivatal) 2017. évi februári lekérdezése alapján. Az adatok a lekérdezés időpontjában még nem voltak véglegesek, ezért eltérnek a tanulmányban leírtaktól.

Statisztikai Szemle, 96. évfolụam 5. szóm 489-521. oldal 
Az IFRS-t alkalmazó, illetve az összes társas vállalkozás ágazatonkénti száma és megoszlása, 2017. február

\begin{tabular}{|c|c|c|c|c|}
\hline Ágazat & $\begin{array}{l}\text { IFRS-t alkalmazó } \\
\text { társas vállalkozás } \\
\text { (db) }\end{array}$ & Megoszlás (\%) & $\begin{array}{l}\text { Összes társas } \\
\text { vállalkozás } \\
\text { (db) }\end{array}$ & Megoszlás (\%) \\
\hline Szállítás és raktározás & 41 & 32,3 & 13311 & 3,3 \\
\hline Pénzügyi, biztosítási tevékenység & 37 & 29,1 & 9659 & 2,4 \\
\hline Feldolgozóipar & 9 & 7,1 & 33796 & 8,4 \\
\hline Kereskedelem & 9 & 7,1 & 92713 & 23,1 \\
\hline $\begin{array}{l}\text { Szakmai, tudományos múszaki } \\
\text { tevékenység }\end{array}$ & 8 & 6,3 & 62067 & 15,5 \\
\hline Információ, kommunikáció & 7 & 5,5 & 21077 & 5,3 \\
\hline Ingatlanügyletek & 7 & 5,5 & 31456 & 7,9 \\
\hline Villamosenergia-, gáz-, gőzellátás & 3 & 2,4 & 917 & 0,2 \\
\hline $\begin{array}{l}\text { Adminisztratív és szolgáltatási } \\
\text { tevékenység }\end{array}$ & 2 & 1,6 & 20107 & 5,0 \\
\hline Egyéb & 2 & 1,6 & 49083 & 12,3 \\
\hline Építőipar & 1 & 0,8 & 34217 & 8,6 \\
\hline Szolgáltatás és vendéglátás & 1 & 0,8 & 18530 & 4,6 \\
\hline Mező- és erdőgazdálkodás & 0 & 0 & 11708 & 2,9 \\
\hline Bányászat & 0 & 0 & 484 & 0,1 \\
\hline Vízellátás, szennyvízkezelés & 0 & 0 & 1716 & 0,4 \\
\hline Összesen & 127 & 100,0 & 400841 & 100,0 \\
\hline
\end{tabular}

Megjegyzés. A táblázatban az összes társas vállalkozás esetén 2016. évi adatok szerepelnek. Forrás: Umenhoffer [2017].

A szállítás, raktározás ágazatban, a pénzügyi szektorban, valamint a feldolgozóiparban múködik az IFRS-t választó gazdálkodóegységek 68,4 százaléka. A pénzügyi szektor részaránya 2018-tól tovább emelkedik majd, hiszen a hitelintézetek számára az IFRS-re való áttérés ettől az évtől kötelező. Jelen cikk készítésekor 48 vállalkozás jelezte, hogy 2018. évtől IFRS szerint vezeti könyveit, ebből 32 hitelintézet vagy pénzügyi vállalkozás.

A nemzetközi könyvvizsgáló cégek felmérése szerint nagyjából ezer gazdálkodóegység átállására lehet számítani az IFRS 2016. évi hazai bevezetését követő években. Ezek között olyan vállalatok is szerepelnek, amelyek a magyar számviteli szabályok szerint készítik éves beszámolójukat, de az IFRS alapján kell, hogy adatokat szolgáltassanak az anyavállalatuk felé; így számukra jelentős adminisztrációs terhet jelent az Szt. és az IFRS szerinti nyilvántartások együttes vezetése. 
Az IFRS-re való áttérés a jövőben várhatóan a jelenleginél lassabb ütemüvé válik, mert az jelentős informatikai és információs rendszerbeli fejlesztéseket igényel, ugyanakkor az IFRS-sel foglalkozó szakemberek száma sem elegendő, és a várható adóhatásokat is alaposan mérlegelik a vállalkozások.

\section{Az IFRS alkalmazásának nemzetközi statisztikai kerete}

Az Európai Unió statisztikai hivatala, az Eurostat 2000-ben hozta létre a Számvitel és Statisztika Munkacsoportot (Task Force on Accounting and Statistics), amely néhány évvel később a CMFB (Committee on Monetary, Financial and Balance of Payments Statistics - Monetáris, Pénzügyi és Fizetésimérleg-bizottság) javaslatára az Eurostat és az Európai Központi Bank közös munkacsoportjává alakult át. Mandátuma értelmében a munkacsoport volt hivatott koordinálni az 1606/2002/EK rendeletből adódó munkát, azonosítani a szükséges lépéseket, illetve megvizsgálni a bevezetés statisztikai hatásait nemzeti és uniós szinten egyaránt. Ennek megfelelően figyelemmel kísérte az IFRS európai bevezetését, közremüködött az azokat alkalmazó szervezetek számviteli adatai, valamint a különböző típusú (többnyire a nem pénzügyi vállalatok nemzeti és pénzügyi számláival összefüggő, illetve a gazdaság-) statisztikai adatok taxonómiáinak kifejlesztésében, és javaslatot tett e taxonómiák használatára annak érdekében, hogy a vállalkozások adminisztratív terhei csökkenthetők és a statisztikai adatgyüjtés hatékonysága növelhető legyen.

A munkacsoport tevékenységének egyik fontos eredménye, hogy „összehozta” a számviteli szakértőket és a statisztikusokat. A közös munka során megkezdődött a számviteli és a statisztikai standardok összehasonlítása, valamint a pénzügyi beszámolásra vonatkozó követelmények és a statisztikai előírások közötti fö kapcsolódási pontok, „hidak” meghatározása, kiépítése.

2004-re a szakemberek azonosították azokat a statisztikai mutatókat, amelyek idősorában törést valószínüsítettek az IFRS 2005. évi európai bevezetése miatt. A standardokat eleinte csak a tőzsdén jegyzett vállalatok konszolidált beszámolóinak készítéséhez használták, mivel a nemzetközi munkacsoport úgy ítélte meg, hogy az IFRS fokozatos kiterjesztése egyedi beszámolási célra nagymértékben megnövelné az idősorokban bekövetkező törések kockázatát. Tovább bonyolítják a helyzetet a tagállamok közötti jelentős eltérések az IFRS-bővítésben érintettek körében, így további kockázatot jelent, hogy elvesznek összehasonlítható statisztikai információk.

A munkacsoport a statisztikák négy csoportjára fókuszált: 1 . a vállalkozások éves SBS-ére (structural business statistics - vállalkozások gazdaságszerkezeti statisztikái), amely lényegében számviteli információkon alapul; 2. pénzügyi és bankstatisztikákra; 
3. fizetésimérleg-statisztikákra és 4. a nemzeti számlákra. Vizsgálatának eredményeit és az azok alapján megfogalmazott ajánlásokat módszertani dokumentumokban foglalta össze, illetve tárta az Eurostat és a tagállamok elé. A négy statisztikai témakör közül elsőként az SBS-t és a pénzügyi statisztikákat vizsgálta, tekintve, hogy e két területen a legkönnyebb a számvitel és a statisztika közötti összefüggések megragadása, ezeken áll a lehető legtöbb számviteli információ rendelkezésre az elemzéshez.

A munkacsoport által megfogalmazott ajánlások közül a következőkben kettőt emelünk ki.

\subsection{A számviteli és a statisztikai adatok összeegyeztethetősége}

Az első ajánlás a statisztika keretén belül tartja a statisztikai szempontból szükséges adatokhoz való hozzáférés problémáját. Megfelelő kiindulási alapot teremt, hogy a statisztikai adatszolgáltatások számviteli adatokon nyugszanak, ráadásul a számviteli pénzügyi kimutatásokban fellelhetö adatok és információk - esetenként módszertani kiigazításokkal - szerkezetileg megfeleltethetők a statisztikai adatigényeknek. Az Eurostat SNA- (system of national accounts - nemzeti számlák rendszere) kézikönyve (Eurostat [2014] 104. old.) szerint az IFRS általános szabályai és módszerei az időbeli elhatárolások elvének alkalmazása, a kettős könyvviteli rendszerben való gondolkodás, valamint a pénzügyi jellegü értékelések tekintetében konzisztensek az SNA rendszerével.

Ha a nem pénzügyi vállalkozások számviteli kimutatásaiból indulunk ki, a következő számviteli-statisztikai megfelelések vázolhatók fel.

3. táblázat

Nem pénzügyi vállalkozásokra vonatkozó számviteli és statisztikai megfelelések

\begin{tabular}{l|l|l}
\hline \multicolumn{1}{c|}{ Pénzügyi kimutatás tétele } & \multicolumn{1}{c}{$\begin{array}{c}\text { Pénzügyi kimutatás, } \\
\text { melyben az adat részben fellelhető }\end{array}$} & \multicolumn{1}{c}{ SNA-aggregátum } \\
\hline Nettó árbevétel & Eredménykimutatás & P.1 Kibocsátás \\
\hline $\begin{array}{c}\text { Egyéb bevételek } \\
\text { Saját elóállítású befektetett eszközök }\end{array}$ & Eredménykimutatás & P.1 Kibocsátás \\
\hline $\begin{array}{c}\text { Késztermékek és félkész termékek } \\
\text { állományváltozásai }\end{array}$ & Eredménykimutatás & P.1 Kibocsátás \\
\hline $\begin{array}{c}\text { Eladott áruk beszerzési értéke (vásá- } \\
\text { rolt áruk esetén) }\end{array}$ & Eredménykimutatás & P.1 Kibocsátás \\
\hline $\begin{array}{c}\text { Áruk és szolgáltatások értékesítési } \\
\text { költségei (saját termelés esetén) }\end{array}$ & Eredménykimutatás & P.1 Kibocsátás \\
\hline
\end{tabular}

(A táblázat folytatása a következö oldalon.) 


\begin{tabular}{|c|c|c|}
\hline Pénzügyi kimutatás tétele & $\begin{array}{l}\text { Pénzügyi kimutatás, } \\
\text { melyben az adat részben fellelhető }\end{array}$ & SNA-aggregátum \\
\hline $\begin{array}{l}\text { Egyéb müködési ráfordítások (sze- } \\
\text { mélyi jellegü ráfordítások nélkül) }\end{array}$ & Eredménykimutatás & P.2 Folyó termelőfelhasználás \\
\hline Készletek állományváltozása & $\begin{array}{l}\text { Adott és előző évi mérleg vagy } \\
\text { cash flow kimutatás }\end{array}$ & P. 52 Készletváltozás \\
\hline Befektetések befektetett eszközökbe & Cash flow kimutatás & P.5 Bruttó/Nettó felhalmozás \\
\hline $\begin{array}{l}\text { Befektetett eszközök értékesítése, } \\
\text { elidegenítése }\end{array}$ & Cash flow kimutatás & P.5 Bruttó/Nettó felhalmozás \\
\hline Személyi jellegü ráfordítások & Eredménykimutatás & D.1 Munkavállalói jövedelem \\
\hline Nettó kamat & Eredménykimutatás & D.4 Tulajdonosi jövedelem \\
\hline Fizetett osztalék & $\begin{array}{l}\text { Cash flow kimutatás, sajáttőke- } \\
\text { tábla }\end{array}$ & D.4 Tulajdonosi jövedelem \\
\hline Adott és előző évi nyereségadó & Eredménykimutatás & $\begin{array}{l}\text { D.5 Folyó jövedelem- } \\
\text { és vagyonadók }\end{array}$ \\
\hline
\end{tabular}

Forrás: Eurostat [2014] 104. old. 5.1. táblázat.

Ugyanakkor vannak mind a nemzeti számviteli szabályokban, mind az IFRS-ben olyan megjelenítési és értékelési elöírások is, amelyek nem azonosak a statisztikai értelmezésekkel. Ezért ki kell építeni hidakat a statisztika és a számvitel között, lehetővé téve a számviteli adatok statisztikai szintű kiigazítását.

E kérdést a statisztika felöl közelítve, kiigazítást igényel például a számviteli nettó árbevétel, melyet csökkenteni kell, ha az termékadókat tartalmaz, illetve termeléshez kapott támogatás esetében növelni kell annak érdekében, hogy az alapáron számított kibocsátás értékéhez jussunk.

Egy másik kiigazítást igénylő tétel a készletek állományváltozása, amit a számvitelben a nyitó és a záró értékek különbségeként, míg a nemzeti számlák rendszerében a készletek ki- és beáramlása alapján mérnek. Erre példaként lehet említeni az alapanyagok folyó termelöfelhasználását, ami általában nem közvetlenül vásárlás, hanem készletfelhasználás útján történik. A nemzeti számlák rendszerében a készletfelhasználást a kivételezés időpontjában érvényes piaci áron értékelik, míg a számviteli elszámolásokban múltbeli bekerülési értéken. E kettő különbségét a nemzeti számlák rendszere készlettartási nyereségként vagy veszteségként számolja el, mely a statisztikai kibocsátásértéket módosítja.

Az előbbi két példán túl az értékcsökkenést is eltérő módon kezeli a számvitel és a nemzeti számlák rendszere, így ezeket az értékeket is meg kell egymásnak feleltetni. ${ }^{5}$

\footnotetext{
${ }^{5}$ Cikkünk 5. fejezetében részletesen ismertetjük és elemezzük a feltárt módosító tételeket.
} 
A statisztika szempontjából felmerülő kiigazításokra számtalan példát lehetne még felsorolni, ám ezek a számviteli-statisztikai adatok összerendelhetőségi problémájának csak egyik oldalát képezik. A másik oldal a számvitelből ered: meg kell vizsgálni, hogy az IFRS-re való áttérés miatt szükséges-e a statisztikai mutatók újraértelmezése, más jellegủ statisztikai adatok bekérése. Az országos mutatók számításához és a nemzetközi statisztikai adatszolgáltatási kötelezettségek teljesítéséhez elengedhetetlen, hogy a hiányzó vagy a tartalmilag nem megfelelő adatok begyüjtése érdekében statisztikai célú, kiegészítő adatszolgáltatásokra kerüljön sor az IFRS-re áttérő vállalkozások esetében. Tekintve, hogy a statisztika nem öncélú adatgyüjtés, hanem a gazdaságpolitikai döntéshozatal eszköze, e többlet-adatszolgáltatási igényt a gazdaság minden szereplöjének tudomásul kell vennie, ellenkező esetben ugyanis nem biztosíthatók teljes gazdaságra vonatkozó, konzisztens, megalapozott statisztikai információk.

\subsection{Az adatszolgáltatások során gyưjtött adatok informatikai feldolgozása}

Az Eurostat által megfogalmazott második ajánlás megvalósítása túlmutat a statisztikán, ugyanis széles körü uniós és nemzeti kormányzati egyeztetést, együttmüködést igényel. Világszerte számos szervezet (például az angol, a német, a dán, a spanyol, a szingapúri cégnyilvántartási rendszer, az Egyesült Államok Értékpapír- és Tőzsdefelügyeleti Bizottsága, a japán EDINET [electronic disclosure for investors' network - a befektetők hálózatának elektronikus közzétételi rendszere] stb.) alkalmazza az ún. XBRL- $\mathrm{t}^{6}$ (extensible business reporting language - kiterjeszthető üzleti beszámolási nyelv) adatok gyüjtésére, feldolgozására és XLS-formátumú adatszolgáltatásokra. Bevezetése hatalmas elörelépést jelentene, és adatszolgáltatói tehercsökkentéssel járna az IFRS-t egyedi beszámolási céllal választó gazdálkodóegységek számára.

A hazai és a nemzetközi szakirodalom alapján (Kloeden [2006], Mohai-Végh [2007], Ahrendt [2009], Dunne et al. [2009]) az XBRL egy üzleti jelentések készítésére szolgáló XML- (extensible mark-up language - kiterjeszthető jelölőnyelv) formátum. Lényege, hogy egyedi elektronikus azonosítót használ minden adat azonosítására, és az ahhoz kapcsolódó információkat explicit módon határozza meg annak érdekében, hogy a különböző programok könnyedén tudják azokat olvasni. Az XBRL emellett tartalmazza a különböző jellegü információk és adatok közötti kapcsolatokat, magában foglal hivatkozásokat számviteli standardokra vagy más forrásokra, valamint le is tudja fordítani azokat különböző nyelvekre. E jellemzők azt eredményezik, hogy az XBRL-lel jobban automatizálhatók lesznek olyan, különböző

\footnotetext{
${ }^{6}$ További információkért lásd xbrl.org
} 
alkalmazások együttes működését szolgáló eljárások, amelyek jelenleg még kézi vezérlést igényelnek. A rendszerben továbbított adatokat, információkat másolás és mentés nélkül lehet feldolgozni, így az XBRL használata mindenhol nagy elörelépést jelent, ahol statisztikákkal, jól és egyértelmủen definiált adatokkal dolgoznak. Nagymértékben megkönnyíti az üzleti és a pénzügyi információk ellenőrzését, összesítését, elemzését, és egyúttal javítja a cégek által felhasznált információk minőségét, az információk megszerzésének gyorsaságát, teljességét, illetve összehasonlíthatóságát, segítve ezáltal a döntéshozatali folyamatot. Hosszú távon csökkenti a jelentések nagyrészt manuális készítésének költségeit azáltal, hogy biztosítja a belső kontroll megbízhatóságát.

A pénzügyi válságot követően az EU-ban a nagyvállalatok felügyeletét (bizonyos korlátozásokkal és kivételekkel) egy intézményhármas vette át: a hitelintézetekét az EBA (European Banking Authority - Európai Bankhatóság), a biztositókét az EIOPA (European Insurance and Occupational Pensions Authority - Európai Biztosítás- és Foglalkoztatóinyugdíj-hatóság), míg a tőzsdén jegyzett, nem pénzügyi vállalatokét és a pénzügyi piacokét az ESMA (European Securities Markets Authority Európai Értékpapírpiaci Hatóság). Egyéb tevékenységeik mellett ezek az intézmények határozzák meg azoknak a jelentéseknek a pontos tartalmát és formáját, amiket a hatáskörükbe tartozó vállalkozásoknak el kell készíteniük, kielégítve a jogszabályok által előírt adatszolgáltatási kötelezettségüket. A feladatban élen járó EBA felügyeleti adatszolgáltatással kapcsolatos útmutatói IFRS-cikkelyre mutató hivatkozással, IFRS-taxonómia szerint, részletes bontásban tartalmazzák a hitelintézetek által XBRL adatszolgáltatási formátumban szolgáltatandó adatokat. 2017-re (a biztosítók számára) az EIOPA és (a tőzsdén jegyzett nem pénzügyi vállalatok számára) az ESMA is kidolgozta az XBRL-alapú adatszolgáltatás keretét és szabályait, így az adatgyüjtést már azt használva kell végrehajtani. ${ }^{7}$

Az XBRL-t az MNB és a NAV is alkalmazza, mikor adatszolgáltatási kötelezettségüket teljesítik egyes nemzetközi felügyeleti szervezetek felé. A felügyeleti adatszolgáltatásra vonatkozóan először az EBA fogalmazta meg, hogy az adatszolgáltatási kötelezettségeket XBRL és DPM (data protection management - adatvédelmi rendszer) használatával kell teljesíteni, a 2015-2017. éves tervében pedig már az olvasható, hogy az ún. első szintủ felügyeleti jelentéseknek ${ }^{8}$ is XBRL-formátumban kell készülniük.

\footnotetext{
${ }^{7}$ Lásd www.eiopa.europa.eu és www.esma.europa.eu

${ }^{8}$ A hitelintézetek és befektetési vállalkozások prudenciális követelményeire vonatkozó 575/2013/EU parlamenti és tanácsi rendelet betartásának ellenőrzésére szolgáló 680/2014/EU bizottsági végrehajtási rendelet végrehajtás-technikai standardokat állapít meg. E standardok értelmében az adatszolgáltatás két lépcsőben valósul meg a következők szerint: 1 . adatküldés az intézmények által a nemzeti felügyeleti hatóságok (MNB) részére; illetve 2. adatküldés a nemzeti felügyeleti hatóságok által (MNB) az EBA felé. Az EBA az EU-szinten egységes adatszolgáltatás érdekében a nemzeti felügyeleti hatóságoktól azonos formátumban kéri az adatokat, amelyeket az általa közzétett XBRL-taxonómia alapján kell eloállítani.
} 
Az IFRS Taxonómiacsoportja vállalta fel, hogy kidolgozza az IFRS-re áttért vállalatok adatszolgáltatásának XBRL-alapú környezetét, és előmozdítja annak globális alkalmazását. Magyarországon 2007-ben készült el az IFRS első XBRLtaxonómiafordítása, amit 2012-ben aktualizáltak, de az XBRL-t még nem használják széles körben pénzügyi beszámolók esetén.

Mivel a taxonómia folyamatosan változik, az adatok kódolása és dekódolása időigényes és komplex feladat, az adatállományok pedig a számos leíró és azonosító mező miatt igen nagyok. Így az XBRL alkalmazása a statisztikai adatszolgáltatások teljes körére valószínüleg nem célravezető, de a témáról igazán csak hatástanulmányok és költség-haszon elemzések végzése után lehet érdemben nyilatkozni.

A tanulmányban vizsgált szakstatisztikák és az IFRS közötti eltérések kiigazításához szükséges adatok jelentős része kinyerhető a vállalkozások mérlegből, eredménykimutatásból és kiegészítő mellékletből álló pénzügyi kimutatásából. Míg az elöbbi kettő jól strukturált adatbázisként, addig a kiegészítő melléklet pdfformátumban áll rendelkezésre, és csak manuálisan kereshető, ami jelentős nehézséget és többletmunkát okoz a statisztikai adatfeldolgozás során. Nyilvánvaló, hogy az IFRS-t alkalmazó vállalkozások számának és gazdasági súlyának növekedésével célszerü egyre inkább törekedni az automatikus adatgyüjtésre. Tekintettel arra, hogy a kiegészítő mellékletben található információk nélkülözhetetlenek a vizsgált szakstatisztikák összeállításához, azokat is strukturált, elektronikus formában kellene elérhetővé tenni minden tagállamban, melyre egy lehetőség az XBRL-taxonómia lehetne.

\subsection{Az IFRS statisztikai alkalmazásának nemzetközi tapasztalatai}

Az előbbieket összegezve megállapítható, hogy az IFRS bevezetése kockázattal jár a statisztikára, a statisztikai adatok minőségére és megbízhatóságára nézve, bár még nem készült részletes felmérés vagy elemzés e témáról az EU-tagországokban.

Az Eurostat IFRS-szakértőivel folytatott egyeztetés arra világított rá, hogy csak akkor szabad átállni az IFRS egyedi alkalmazására, ha azzal párhuzamosan nemcsak a statisztikai, hanem az adózási és más, hatósági célokat szolgáló adatszolgáltatások is standardizálhatók a tagországok igényeire szabottan. Ésszerünek tünik, és az ütemterve is életszerü annak a megoldásnak, ami az ESMA által kidolgozott sablonból kiindulva építi fel az adatszolgáltatással kapcsolatos átfogó módszertanváltást. Ennek megvalósításához egy nagy, átfogó, egységes és közös rendszer kidolgozására van szükség a teljes (ESA 2010 [European System of Accounts - Nemzeti Számlák Európai Rendszere] szerinti) vállalati szektort tekintve. Feltétele, hogy az adott tagországban az összes felügyeleti, adatgyüjtő és -feldolgozó intézmény (az adóhivatal, a jegybank, a statisztikai hivatal, a cégbíróság stb.) szorosan együttmüködjön. 
A tagországokban az IFRS bevezetésére - ahol az már megtörtént - széles körü kormányzati és vállalati összefogással került sor, és a folyamat több évig tartott. Ha az IFRS-t egyedi beszámolásra is alkalmazzák, a hiányzó/tartalmilag nem megfelelő adatok begyüjtése statisztikai többletterhet jelent, vagy az IFRS által megszabott minimumkövetelményeknél részletesebb, kötelező beszámolási elöírások alapján történik annak érdekében, hogy statisztikai, adózási, ellenőrzési, illetve felügyeleti célokra is elegendő információ álljon rendelkezésre.

Az IFRS-re való átállás statisztikai folyamatai és a végrehajtás során szerzett tapasztalatok nagyban különböznek egymástól az egyes tagállamokban, hiszen azokat a korábbi, IFRS elött müködtetett számviteli rendszer is meghatározza. A balti országokban régebben nem létezett nemzeti számviteli szabályozás, így ök könnyen be tudták vezetni az IFRS-t. Az Egyesült Királyság GAAP-ja (generally accepted accounting practice - általánosan elfogadott számviteli gyakorlat) pedig közel állt az IFRS szemléletéhez, így azt az eltérések feltérképezése után csak módosították, de nem változtatták meg alapjaiban (Hobbs [2005]).

Arra azonban nincs precedens, hogy az egyedi beszámolási célokra is engedélyezett IFRS-rendszer egy hozzá nem közel álló (nem angolszász-alapú), de már létező és jól müködő, statisztikai adatszolgáltatás alapjául szolgáló számviteli szabályozást váltott volna fel. Például Németországban, ahol - Magyarországhoz hasonlóan - a nemzeti számviteli szabályozás központosított, nem keretjellegü, hanem konkrét szabályokon alapszik, államigazgatási szinten még nem született egységes megállapodás az IFRS egyedi beszámolási célra való alkalmazásáról.

A KSH (Központi Statisztikai Hivatal) az NGM (Nemzetgazdasági Minisztérium), a NAV és az MNB IFRS-bevezetéssel foglalkozó szakembereivel együttmüködve dolgozta ki a magyar nemzetgazdasági statisztikák elöállításához szükséges, IFRS-alapú adatszolgáltatás keretét, illetve határozta meg annak elemeit.

\section{Az IFRS alkalmazásának magyarországi statisztikai kerete}

Az 1639/2014. (XI.14.) Korm. határozat nyomán életre hívott statisztikai munkacsoport 2014 végén/2015 elején indított széles körü egyeztetést a statisztikai adatgyüjtésben és adat-elóállításban elsődlegesen, illetve áttételesen érintett szervezetek (a KSH, az MNB, a NAV, az NGM), valamint négy nagy könyvvizsgáló cég (Big4) képviselöi között.

A KSH és az MNB statisztikai munkája során a társasági adóbevallásnak a számviteli éves beszámolókénál részletesebb egységes mérleg- és eredménykimutatási adataira támaszkodik, amelyek a gazdaságstatisztikai számítások és makroelemzések

Statisztikai Szemle, 96. évfolụam 5. szóm 489-521. oldal 
elsődleges adminisztratív forrását képezik. A jelenlegi gyakorlat - elsősorban alacsony költségvonzata, valamint az adatszolgáltatói terhekre és a statisztika minőségére gyakorolt kedvezö hatása miatt - nemzetközi értelemben is fejlett módszernek tekinthető. Nemcsak az adatszolgáltatókat kíméli meg újabb adatszolgáltatói terhektől, de egyben nemzetgazdasági szintü költségmegtakarítást is jelent például a többszörös adatfeldolgozás elkerülésével. Az éves társasági adóbevallás mérlege és eredménykimutatása kielégíti a magyar statisztikai szolgálat általános éves adatigényét. Az így elóállított adatállomány mind a mintavételes felvételek, mind a regiszterépítés alapjául szolgál, mely nélkül a statisztikai alapsokaság nem ismerhető meg.

Az IFRS egyedi beszámolási célra történő bevezetése új helyzetet teremtett a statisztikai szolgálat számára, mivel - az IFRS-rendszer alkalmazásával párhuzamosan - változatlanul eleget kell tennie a magyarországi törvényi elöírásoknak és a nemzetközi statisztikai beszámolási kötelezettségeinek. Az első elemzések szerint az éves társasági adóbevallásban bekért információk - szinte változatlan formában, azonban nem minden esetben változatlan tartalommal - rendelkezésre állnak az egyedi IFRSbeszámolót választó adatszolgáltatók esetében is. Így a statisztikusokra hárul az a feladat, hogy részletes, tételes vizsgálatnak vessék alá a társasági adóbevallás statisztikai célokat szolgáló tételeit, és azonosítsák azokat a területeket, ahol az IFRS és a magyar számvitel eltéréseinek nemzetgazdasági szintủ hatásuk lehet. A legnagyobb kihívást a szemléletbeli különbségek jelentik, hiszen az IFRS keretjellegü megjelenítési és értékelési elvei, konkrét előírásai meglehetősen távol állnak a kötött, számos esetben taxatív felsorolással szabályozó magyar számviteltől.

Az IFRS-adatforrású statisztika kidolgozásával kapcsolatban a következő kérdések merültek fel:

- Hogyan és milyen szinten kell figyelembe venni a magyar számvitel és az IFRS eltéréseit? Lehet-e cél, illetve végrehajtható-e azok tételes levezetése?

- Újra kell értelmezni a statisztikai mutatókat?

- Törésmentesek maradnak-e, vagy töréseket fognak mutatni az idősorok?

- Lesz-e makroszintủ hatása az IFRS alkalmazásának?

- Miként oldható meg, hogy ne jelentsen többletterhet az adatszolgáltatási kötelem?

Az IFRS bevezetésekor a kormányzati célkitüzés az volt, hogy ne járjon adminisztratív többletteherrel az alkalmazók számára, illetve, ne „forgassák azt vissza” a magyar számvitelre. Ebből adódóan már az IFRS-re vonatkozó statisztikai munka elején megfogalmazódott, hogy nem lehet törekedni a magyar számviteli elöírások és az IFRS közötti eltérések tételes levezetésére, és az nem is kivitelezhető. A fö feladat 
így a statisztikai szempontból lényeges, nagyobb különbségek feltárása, mely adott esetben egy-egy mutató (de legalábbis az ahhoz addig felhasznált információk) újraértelmezésével járhat. Ennek megfelelően a szakemberek nem csupán a magyar számvitel és az IFRS, hanem a számviteli standardok és a nemzetközi statisztikai elóirások közötti tartalmi különbségeket is elemezték, megoldásokat vázolva fel azok kezelésére. Ezen túl újrafogalmazták a statisztikai adatgyüjtések és a társasági adóbevallás definícióit is.

Munkájuk során arra a megállapításra jutottak, hogy a magyar szakstatisztikai fogalmak sok esetben közelebb állnak az IFRS-hez, mint a magyar számvitel által használtakhoz. (Erre jó példa az SBS-ben szereplő hozzáadott érték és az annak megfelelö IFRS-fogalom.) Az SBS és az IFRS között azonban ezzel együtt is számtalan különbség tárható fel, pusztán azok más-más célja, szabályozási logikája és elvei miatt. A következőkben azokat az eltéréseket emeljük ki, amelyek elsődleges átgondolást és megoldást igényeltek (ISTAT et al. [2011]):

- Az SBS árbevételként a számlázott értéket tekinti, nem korrigálja az árbevételt olyan tételekkel (például a visszaküldési joggal terhelt szerződések árbevétel-kockázatával vagy egyéb becsült elemekkel), amelyeket az IFRS 15. Vevőkkel kötött szerződésekből származó bevételek standard megkövetel. Az SBS árbevételeként az adókkal növelt összeget kell érteni, az IFRS árbevételeként pedig az azoktól „megtisztítottat”. Míg a kapott támogatások értéke az IFRS-ben megjelenhet az árbevételben, az SBS-ében nem.

- Az IFRS-ben akár összköltség-, akár forgalmi típusú eredménylevezetés készül, a beszerzett készletek és szolgáltatások értéke számos olyan elemet tartalmazhat, amit az SBS szerinti nem. Ennek oka, hogy az IFRS-ben nincs szigorúan szabályozott besorolás, a gazdasági esemény tartalma és a vállalkozás döntése határozza meg, miként számolják el, mutatják ki a beszerzett készletek és szolgáltatások értékét. Például az ún. egyéb müködési költségek IFRS-kategória az SBS-hez szükséges tételek mellett számos más elemet (értékvesztést, céltartalékot, adókat stb.) is tartalmazhat, amelyek az SBS beszerzett készletek és szolgáltatások értékében nem jelennek meg. Így eldöntendő, hogy vajon rá kell-e külön kérdezni a statisztikai adatszolgáltatás során az SBS szempontjából releváns költségtípusokra, hiszen azok az IFRS pénzügyi kimutatásaiban fellelhetők, csak az nem azonosítható be, hogy pontosan hol.

- Az SBS-ben a készletek értéke tartalmazza az adókat (kivéve a visszaigényelhető áfát), míg az IFRS-ben az adók nem jelennek meg minden esetben. 
- Az IFRS-ben a kapott támogatások összege nettó módon is elszámolható, azaz egy igénybe vett szolgáltatáshoz kapcsolódóan kapott támogatás levonható magából az igénybe vett szolgáltatás költségeiből. Ha az IFRS-t alkalmazó szervezet ezt az elszámolási módot választja, akkor az SBS-ben a költségek értékét növelni kell a támogatás összegével.

- Az IFRS-ben, mivel a könyvelés módja nem szabályozott, az STKÁV (saját termelésű készletek állományváltozása) nem minden esetben jelenik meg (még akkor sem, ha a vállalkozás összköltségeljárással készíti eredménykimutatását), így a nettósított elszámolást gyakran alkalmazzák a vállalkozások. Ekkor az SBS-hez az STKÁV a saját termelésủ készletek záró és nyitó értékeinek különbségeként számítható a mérlegből.

Az IFRS alkalmazásának és az azzal járó változások makrohatásainak bemutatása érdekében elengedhetetlen volt, hogy a KSH új eljárásokat és szakstatisztikai (adatelőállítási) módszertant dolgozzon ki. Fel kellett készülnie az idősoros adatokban megjelenő törések módszertani elemzésére és magyarázatára, szükség esetén az idősorok egységes módszertan szerint „,visszavezetésére”. Az idősorokban bekövetkező törések, a két rendszer közötti eltérések nem kielégítő magyarázata a megbízhatatlanság és az összehasonlíthatatlanság látszatát keltheti, ezért a hivatal egyik legfontosabb célkitüzése azok elkerülése kell, hogy legyen.

A következő lépésként a KSH azt vizsgálta, hogy a nemzeti számlák összeállítása során az IFRS egyedi beszámolási célú alkalmazása milyen besorolási és értékelési eltéréseket idézhet elö, illetve milyen hatásokat gyakorolhat a statisztikai adatokra.

A nemzeti számlák fö feladata a makrogazdasági aggregátumok (például a GDP és a GNI [gross national income - bruttó nemzeti jövedelem]) összeállítása egységes elszámolási elvek és módszertan alkalmazásával, biztosítva a nemzetközi összehasonlíthatóságot. Az EU-ban ez az ESA 2010 alapelvei szerint történik. Minden tagország számára kötelező részletesen leírni az ún. GNI Inventory-ban (Jegyzék) ${ }^{9}$ a számítások módszertanát. A GDP/GNI számításának kiindulási alapját a szakstatisztikákból nyert, zömmel számviteli adatokra épülő információk képezik, melyekből a nemzeti számlák uniós módszertani standardja szerint az ESA transzformációjával, az ún. ESA-hidak alkalmazásával lehet eljutni a nemzeti számlákban publikált adatokig. Az EU ezeket az adatokat használja a tagországok GNI-alapú költségvetési befizetésének meghatározásához (Murai [2011]). A jogszabályi elóírások és az elszámolási elvek alkalmazását,

\footnotetext{
${ }^{9}$ A nemzeti számlákban szereplő adatok megbízhatóságáról az alapadatoktól a transzformációkig minden tagállamnak időről időre egy több száz oldalas, minden részletre kiterjedő dokumentumban, a GNI Inventoryban kell számot adnia. A számítások menetét az EU folyamatosan ellenőrzi, és helyszíni ellenőrzések keretében vizsgálja; minőségi hibák esetén bírságolhat, illetve kötelezettségszegési eljárást indíthat.
} 
illetve az adatok minőségét az Európai Bizottság helyszíni ellenőrzések során vizsgálja. E célra egységes táblarendszert alkottak, ami áttekintést ad az adatforrásokról és a GDP/GNI számításához használt becslési eljárásokról. Alapkoncepciója az, hogy a számítások adatforrásai, valamint az azokon végrehajtott nemzetiszámla-kiigazítások (ESA-hidak) egyértelmüen elkülönüljenek egymástól.

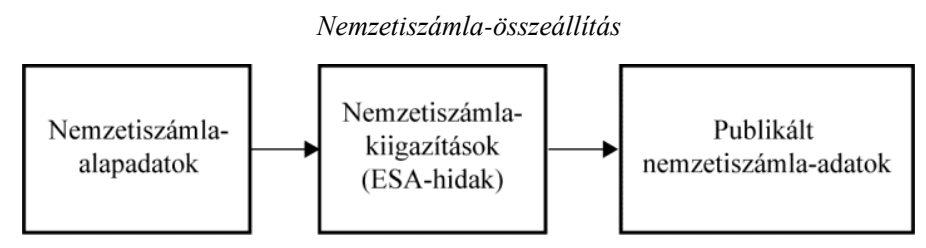

A GDP a termelés, a felhasználás, illetve a jövedelem oldaláról közelíthető meg. Az első kettőn alapuló számítások egyes tételeit jelentősen befolyásolják az IFRSátállás következtében bevezetett módosítások, amelyek mind az alapadatokban, mind az ESA-hidaknál megmutatkoznak.

Termelési oldalról egy adott időszakban előállított termékek és szolgáltatások összegéből indulunk ki, amelyet „megtisztítunk” a termeléshez/szolgáltatáshoz felhasznált termékek/szolgáltatások értékével, vagyis a folyó termelőfelhasználással. Az így alapáron számított, nemzetgazdasági ágak szerinti bruttó hozzáadott értéken még további korrekciók végrehajtása szükséges annak érdekében, hogy biztosítani lehessen az egyezőséget a felhasználási oldal piaci áron számított GDP-jével. A termelési oldalnál ez a korrekció a termeléshez felhasznált termékadók hozzáadásával és a terméktámogatások levonásával érhető el.

A nemzetközi gyakorlat a nemzeti számlák négyféle adatforrását tartja számon, amelyekből a következő hármat közvetlenül is érinti az IFRS-átállás, míg az extrapolációk és modellek esetében a becslésekhez használt alapadatokon keresztül csak közvetett hatása érvényesül:

- kérdőívek, adatfelvételek (statisztikai adatgyüjtések),

- adminisztratív adatforrások (a hazai gyakorlatban ezek közül legfontosabbak az adóbevallások és azokon belül a társaságiadóbevallások, a felügyeleti hatóságoktól származó adatok, illetve a pénzügyi jelentések),

- kombinált adatforrások (az adminisztratív adatforrások és a statisztikai adatgyüjtések kombinációi; az ezek ún. Közös adatbázisát Magyarországon 2009 óta használják a nemzeti számlák vállalatiszektor-input, illetve az SBS adatainak forrásaként: a gazdaságstatisztikai [elsősorban teljesítménystatisztikai] adatgyüjtésből származó adatokat egyedi [vállalkozás-] szinten egészítik ki a társaságiadó-bevallások adataival). 
Az IFRS alkalmazásával összefüggő adatszolgáltatási kötelem miatt átdolgozták és kibővítették a statisztikai kérdőíveket és a társasági adóbevallást, mivel ezek jelentik a legkisebb adminisztrációs terhet a gazdálkodóegységek számára. Lényegében egyfajta statisztikai szemléletváltásra volt szükség, hiszen a hosszú évek alatt kialakított, stabil, részletes (az IFRS elveitől nagyon sok tekintetben eltérő) magyar számviteli információs bázison nyugvó adat-elóállítási folyamat teljes újragondolására volt szükség annak érdekében, hogy az IFRS-re áttérő vállalkozások adatai konzisztens módon legyenek illeszthetők egyrészt a magyar számviteli rendszer szerint beszámolót készítő vállalkozások adataihoz, másrészt a nemzetközi elöírásokhoz.

\section{Az IFRS-alapú statisztika módszertana és alkalmazása}

Annak érdekében, hogy minél szélesebb körben lehessen felhasználni a vállalkozások számviteli nyilvántartásának információit, a nemzeti statisztikai hivataloknak érteniük kell a statisztikai és a számviteli szemlélet közötti különbségeket, illetve hasonlóságokat. Ez elősegíti azt is, hogy az adatszolgáltatók (és a könyvelők) számára könnyen értelmezhető kérdőívek készüljenek. A KSH gazdaságstatisztikai mutatói, valamint a számviteli előírások és az IFRS közötti összefüggéseket, (lehetséges) megfeleltetéseket, eltéréseket bemutató táblák az első lépést jelenthetik a két szemléletmód közötti konzisztencia felé vezető úton.

Ezt a munkát - összhangban a nemzetközi ajánlásokkal - a KSH a számviteli információkkal szoros kapcsolatban levő SBS-mutatók elemzésével, valamint azok IFRS-sel való összevetésével kezdte. Ennek a számviteli összefüggések feltárásán túl az is nagy előnye, hogy e mutatók alapvető fontosságúak az STS (short-term business statistics - rövid távú gazdaságstatisztika) és a nemzeti számlák termelési oldalának számításában. Következésképpen, az IFRS és az SBS összefüggésében tett megállapítások egyúttal a nemzeti számlák esetén is igazak, figyelembe véve természetesen a szakstatisztika és a nemzeti számlák közötti módszertani eltéréseket.

A statisztikai elemzés első szintjén az Szt. és az IFRS szabályait vetették össze, párhuzamba állítva a közöttük levő eltéréseket az IFRS-törvény által a társasági és az iparüzési adó meghatározásához előírt módosító tételekkel. Ezt azért volt indokolt ily módon végrehajtani, mert nem lehetett célkitüzés az Szt. és az IFRS közötti valamennyi eltérés statisztikai szintü visszarendezése, hiszen azzal tulajdonképpen kettős számviteli rendszert kellene müködtetni. A feltárt eltérések jelentős része vagy nem okoz nemzetgazdasági szinten jelentős változást (például a hitelfelvételi költségek aktiválásának sajátosságai [IAS 23. Hitelfelvételi költségek standard]), vagy a magyar és az IFRS-szabályozás annyira különböző, hogy eltéréseik nemzetgazdasági 
szinten nem kezelhetők, és nem értelmezhetők (például az árbevétel értékelése [IAS 11. Beruházási szerződések és IAS 18. Bevételek standardok, illetve 2018. január 1jétől az IFRS 15. Vevői szerződésekből származó bevétel standard]).

E munka megteremtette a számviteli-statisztikai összhangot az IFRS-törvénnyel; a nemzetközi munkacsoportok által elért eredmények és a statisztikai projektek is a KSH munkacsoportja által levont következtetéseket támasztották alá (ISTAT et al. [2011]).

A számviteli rendszerek összehasonlítása során felmerült a számvitelben és a statisztikában alkalmazott fogalmak és definíciók összevetésének témája is. A KSH ebben a kérdésben arra a következtetésre jutott, hogy fogalmi és definíciószinten nincs szükség lényeges változtatásokra, újraértelmezésekre. Azokat a tartalmi témákat kell módosítani, amelyek az eltérő megjelenítésből és értékelésből adódnak.

\subsection{A teljesítménystatisztikai adatgyüjtések (OSAP [Országos Statisz- tikai Adatfelvételi Program] 2235, 2236 és 2239) ${ }^{10}$ IFRS-szemléletü elemzése és annak megállapításai}

Az SBS leglényegesebb kiinduló adata az árbevétel, így ez alapján szemléltetjük az IFRS-sel kapcsolatos statisztikai munkafolyamatot. Az SBS, az Szt., illetve az IFRS árbevétel-definíciója a következő:

- SBS: a tárgyévben értékesített (kész- és félkész) termékek, anyagok, áruk, teljesített szolgáltatások ártámogatással és felárral növelt, regisztrációs, jövedéki és energiaadót tartalmazó, engedményekkel csökkentett, áfát nem tartalmazó ellenértéke. Idetartozik a külföldi székhelyü vállalkozás, illetve annak magyarországi fióktelepe által teljesített termékértékesítés és szolgáltatásnyújtás számlázott, áfa nélküli ellenértéke is.

- Szt. (72-73. §): árbevételként kell kimutatni a szerződés szerinti teljesítés időszakában az üzleti évben értékesített, vásárolt és saját termelésű készletek, valamint a teljesített szolgáltatások ártámogatással és felárral növelt, engedményekkel csökkentett, áfát nem tartalmazó ellenértékét, valamint az árbevételbe beszámító ártámogatást az adóhatósággal történő elszámolás alapján. A számlázott engedmény az árbevétel összegét csökkenti, a nem számlázott engedmény azonban nem árbevétel-módosító tétel.

${ }^{10}$ OSAP 2235: Havi teljesítménystatisztikai jelentés, OSAP 2236: Negyedéves teljesítménystatisztikai jelentés, OSAP 2239: Éves teljesítménystatisztikai jelentés. 
- az IFRS keretelvei általános definíciót adnak. Ezek szerint a bevételek a gazdasági hasznok növekedései a beszámolási időszak alatt, amelyek az eszközök növekedésében vagy a kötelezettségek csökkenésében nyilvánulnak meg, és a tőke növekedését eredményezik (ez alatt a tulajdonosokkal végzett tranzakciókon kívüli eseteket értjük). Az IFRS 15. standardja - mely részletesen értelmezi és értékeli az árbevételt - logikájukat, szemléletüket és megfogalmazásukat tekintve is jelentősen eltérnek a magyar számviteli szabályoktól. Például az IFRS 15. standard alapján az ígért áruk/szolgáltatások vevőnek való átadásákor - tulajdonképpen a gazdálkodó egység teljesítésekor - olyan összegü árbevételt kell megjeleníteni, amely az ellenértéket tükrözi, és amelyre a gazdálkodóegység az említett árukért/szolgáltatásokért várakozása szerint jogosultságot szerez.

\subsubsection{Az árbevétel IFRS-alapú statisztikája}

Az IFRS-törvény úgy fogalmaz, hogy mind számviteli, mind adózási célokat tekintve, az IFRS szerinti árbevételt kell elfogadni, abból kell kiindulni. A KSH ezt az elvet követte a statisztikai árbevétel meghatározásánál is. A teljesítménystatisztikák tekintetében a következő eltéréseket azonosította az Szt. és az IFRS között (emellett minősítette azok statisztikai jelentőségét, és választ adott arra is, hogy - amennyiben szükséges - miként rendezhető az adatszolgáltatás):

a) A közvetített szolgáltatások költsége az IFRS alapján az árbevételt csökkenti (hiszen az nem a vállalkozás saját teljesítménye), míg az Szt. szerint költségként kerül kimutatásra. Ennek az eltérésnek a hatása jelentősnek tekinthetö.

A KSH teljesítménystatisztikai jelentése kiemeli, hogy ez a tétel nem csökkenti a statisztikai árbevételt. Az egyeztetések eredményeképpen az eddigieket kiegészítő, új statisztikai adatszolgáltatás két helyen jelenik meg:

- a teljesítménystatisztikákban az IFRS szerinti árbevételadatot kell megadni, módosítva azt olyan közvetített szolgáltatási árbevételekkel, amelyeket a vállalkozás a magyar számviteli elöírások szerint az árbevételek között szerepeltetett volna, de az IFRS-ben árbevételt csökkentő, nettó módon kerültek elszámolásra.

- az IFRS szerinti társasági adóbevallás eredménykimutatásában kért a KSH adatszolgáltatást (A-06, 3. sor - az eladott [közvetített] szolgáltatások árbevétele a közvetített szolgáltatások költségének levonása után [nettósítva]). 
b) Az IFRS eredménylevezetése csak a folytatódó tevékenységeket mutatja részletesen, soronként, a megszünő tevékenységek eredményét egy sorban tünteti fel. Ugyanakkor az Szt. sem mutatja be külön a megszűnő tevékenységet. Mivel ennek hatása jelentős lehet, a teljesítménystatisztikában a megszünő tevékenység bevételeit (és a ráfordításoknál azok ráfordításait) is be kell számítani a közölt árbevételadatokba.

c) A nem számlázott, utólag adott engedmény, illetve a projekthez kapcsolódó kötbér az IFRS-ben az árbevételt csökkenti, míg az Szt.ben ráfordításként kerül elszámolásra. Ez az eltérés nem minősül számottevő hatásúnak, így statisztikai adatként elfogadható az IFRS szerinti kezelés, az adatszolgáltatóktól nem szükséges többletinformáció bekérése. Megjegyezzük, hogy ezek a tételek az IFRS-rendszerben a társasági adóalap korrekciós tételei között jelennek meg, így, ha a jövőben lényeges elemmé válnának, rendelkezésre állnak rájuk vonatkozó adatok.

d) A hasonló pénzáramot generáló eszközök cseréje az IFRS-ben nettó módon számolandó el, ezért nem eredményez árbevételt és ráfordítást, az Szt. alapján viszont igen. Az eltérés azonban nem tekinthető jelentős hatásúnak, így a statisztika elfogadja az IFRS szerinti elszámolást. Az IFRS-re épülő társasági adóalap korrekciós tételei a hasonló pénzáramot generáló eszközök cseréjére vonatkozó adatokat is tartalmazzák, tehát, szükség esetén, rendelkezésre állnak rájuk adatok.

e) A jövedéki és a népegészségügyi, illetve olyan egyéb adók, amelyek az értékesítési ponthoz (teljesítés időpontjához) kapcsolódnak, az IFRS-ben csökkentik az árbevételt, az Szt-ben viszont jellemzően ráfordítások. Ezek az árbevételre gyakorolt hatások jelentősnek tekinthetők, és statisztikai adatként két jelentésben jelennek meg:

- az IFRS-t alkalmazók esetében a népegészségügyi adót árbevételt növelő tételként kell tekinteni, ha azt ráfordításként számolta el a cég. Az adók másik csoportjánál számviteltől eltérő kezelést kér a statisztika, így a regisztrációs, a jövedéki és az energiaadó összegét le kell vonni az árbevételböl.

- az IFRS szerint készült társasági adóbevallás eredménykimutatásában (A-06, 4. sor) a KSH adatszolgáltatást kér az árbevételben nettó módon elszámolt adó összegére vonatkozóan. Mivel ez egy összesített adat, nem mutatja a mögötte álló adónemeket és azok összegét, így azokra további statisztikai egyeztetéseket és becsléseket kell végezni. 
f) Az IFRS-ben a kapott támogatások elszámolása függ azok jogcímétől (IAS 20. Állami támogatások, közremüködések standard). Ezért, ha a támogatás a költségek finanszírozására szolgál, egyéb bevételként vagy akár árbevételként is elszámolható. Ennek statisztikai hatását úgy lehet kezelni, hogy a teljesítménystatisztikai jelentésben az árbevételnek minősülő (például az ár-) támogatást árbevételként kell feltüntetni. Ezt a kiigazítást nem a jelentés fölapjai adattartalmának bővítésével oldották meg, hanem az útmutató szabályozza. Ezzel a megoldással - ahol erre mód volt - nem kellett a kérdőívek megszokott mutatókörén változtatni és a bekért adatok körét bővíteni.

g) A szolgáltatások árbevételét az IFRS készültségi fok szerint számolja el, az Szt. viszont nem. Bár az egyes évek hatása jelentős lehet, az azokra elszámolt árbevételek ingadozása több évet tekintve kiegyenlítődik. Az Szt. és az IFRS közötti különbségek módszertani és értékelési szempontból olyannyira nagyok, hogy teljesítményjelentésben többletadatok bekérésével nem korrigálhatók. Így, igazodva az IFRS-törvényhez, az IFRS szerinti bevételt kell a statisztikai jelentésben feltüntetni.

h) Az IFRS szerint visszavásárlási kötelemmel terhelt értékesítésként csak olyan árbevétel számolható el, ami bizonyosan realizálható. Eszerint, ha a vállalkozás úgy szerződik, hogy a vevő az árukat meghatározott időn belül visszahozhatja, és a vásárlástól elállhat, akkor csak azt az árbevételt lehet elszámolni, amit tapasztalati adatok alapján a vállalkozás valóban be tud gyüjteni. Az Szt. e kérdésre nem tér ki. A két rendszer közötti eltérésnek összességében számottevő lehet a hatása, de mivel annak statisztikai szintủ kezelése a vállalkozások számára nagy adatszolgáltatási többletterhet jelentene, így attól a KSH eltekint.

i) Az IFRS alapján a kamatmentesen vagy a kedvezményes kamatozással értékesített termékek esetében az árbevételből ki kell emelni a finanszírozási kamattartalmat, ha az jelentősnek minősül. Az Szt. ezt a kérdést sem kezeli. Mivel statisztikai szempontból a két rendszer közötti különbség hatása nem tekinthető meghatározónak, arra külön adatszolgáltatás nem történik, és szabály sem vonatkozik.

Összességében a KSH arra törekedett, hogy a statisztikai adatszolgáltatás ne a teljesítménystatisztikai kérdőívek főlapjain módosuljon, bővüljön. A kért többletadatok a vállalkozások számviteli információs rendszerében analitikus és/vagy fökönyvi szinten rendelkezésre állnak, így kigyüjtésük, közlésük nem okoz jelentős többletmunkát, illetve nem igényli az információs rendszer átalakítását. A megszünő tevékenységek és a közvetített szolgáltatások, valamint az árbevételhez kapcsolódó adó- 
fajták, engedmények elszámolásához köthető eltérések esetén az árbevétel elszámolásával kapcsolatos sajátosságokra az évközi teljesítménystatisztikai kérdőívek kitöltési útmutatója hívja fel az adatszolgáltatók figyelmét, rávilágítva a valószínúsíthetően nagy számszaki eltéréseket okozó tételekre.

\subsubsection{A ráfordítások IFRS-alapú statisztikája}

A teljesítménystatisztikában a ráfordításoknál is azonosíthatók voltak kezelendő eltérések az IFRS és az Szt. között. Ezek egyik része a ráfordítások, költségek különbözö megjelenítéséből és csoportosításából, másik része a nem egyforma értékelési szabályokból adódott. Utóbbiak statisztikai szintủ kezelése nem lehetett feladat, hiszen az ismét kettős (Szt. és IFRS szerinti) nyilvántartást igényelne. A költségek meghatározó részénél ugyanakkor lényeges nagyságrendủ eltéréseket nem lehetett feltárni.

A KSH az IFRS és az Szt. rendszere között a következő eltéréseket azonosította (emellett minősítette azok statisztikai jelentőségét, és választ adott arra is, hogy amennyiben szükséges - miként teljesíthető az adatszolgáltatás):

a) A magyar számviteli elöírások konkrétan meghatározzák, hogy egy adott költséget, ráfordítást mely kategóriában kell megjeleníteni. A nemzetközi számviteli standardok ezzel szemben elvi jellegúek, azaz a ráfordításokat és a költségeket a gazdasági esemény tartalma alapján csoportosítják, sorolják be. Például az Szt. szerint a szakértői díjak anyagjellegü ráfordításnak, azon belül is igénybe vett szolgáltatásnak, míg az IFRS eredménykimutatásában jellemzően egyéb működési ráfordításnak minősülnek (összköltségtípusú eredménykimutatást feltételezve).

b) Másfajta problémát vet fel az IFRS-ben gyakran alkalmazott nettósítás hatása. Előfordulhat, hogy az adott költségtétel azért nem jelenik meg a költségek között, mert beépül egy eszköz bekerülési értékébe, és így azt az eszközök ,átalakulásaként”, nettó szemléletben számolják el, nem pedig hozam-ráfordítás szemléletben.

A teljesítménystatisztika egy további kiigazítandó tétele az STKÁV értéke. Ez a téma azért vetett fel problémákat, mert az IFRS szerinti önköltség és így az állományváltozás értéke nagymértékben eltérhet a magyar számviteli szabályok szerinti összegtől, ami a nettósítással és az önköltségként kezelt tételekkel magyarázható.

Nyilvánvaló, hogy az IFRS és az Szt. közötti lényeges besorolási és nettósítási eltéréseket rendezni kellett a statisztikában, hiszen azok különböző ráfordításértékeket adnak, ami lényegesen módosíthatja a teljesítményadatokat. 
Megoldásként a teljesítménystatisztikai jelentés útmutatója kiemeli az IFRSrendszer értelmezéseit és adatszolgáltatási szabályait.

Az IFRS-t alkalmazóknak

- közvetített szolgáltatások költségeként kell kimutatniuk az árbevétel részeként jelentett ügynöki típusú tevékenység bevételét, illetve az igénybevett alvállalkozói tevékenység értékét is;

- az igénybe vett és egyéb szolgáltatások értékében kell jelenteniük minden, tárgyidőszakban felmerült anyag-, energia- és igénybevettszolgáltatás-költséget, függetlenül attól, hogy azt a késztermék értékében vagy valamely saját elöállítású eszköz értékében feltüntették-e;

- az STKÁV meghatározásakor nem kell kimutatniuk azokat a saját termelésủ készleteket, amelyek értékét a tárgyhónapot megelőzően az árbevétel részeként már jelentették, függetlenül attól, hogy a munka számlázása megtörtént-e.

A saját termelésü készletek önköltségében és állományváltozásában a gyakorlatban alkalmazott eltérő elszámolások és nettósítások lényeges hatásokat eredményezhetnek, de statisztikai szempontból megbízható információ áll elő, ha a statisztikusok, csakúgy, mint eddig, a saját termelésü készletek nyitó és záró állományára kérdeznek rá, amely így megadja az állományváltozás értékét.

Egy másik statisztikai adatszolgáltatási megoldás a társasági adóbevallás. A társasági adóbevallás eredménykimutatásának szerkezetét tekintve ez a megállapítás elsőre megalapozatlannak tünhet, hiszen annak adatai lényegileg megegyeznek az Szt. alapján beszámoló vállalkozásoktól eddig kért adatokkal. Az IFRS szerint beszámoló vállalkozások eredménykimutatásában azonban olyan, meglehetősen összevont eredménykategóriák szerepelnek, mint összköltségeljárás esetén az anyag- vagy a személyi jellegủ ráfordítások, az értékcsökkenés, az egyéb müködési ráfordítás. Ahogy arra már korábban utaltunk, ezek tartalma taxatíve nem meghatározott az IFRS-ben, illetve az eredménykimutatás fölapja alapján a statisztikákhoz részletes adatok nem állnak rendelkezésre. Így a társasági adóbevallásban kért adatokat, amelyek szintén rendelkezésre állnak analitikus és/vagy főkönyvi szinten a vállalkozásoknál, nem szükséges a KSH-nak a számviteli törvény szerinti kiegészítő mellékletben feltárni (ha egyáltalán közölte őket a szervezet). Bár a hivatalnak az volt a célja, hogy a NAV minél több, statisztikákhoz szükséges adatot kérjen a vállalkozásoktól, e szándék érvényesülését az adóhatósággal folytatott egyeztetések és annak az elvnek az alkalmazása, hogy a társaságoknak csak adózási célt szolgáló adatokat kell szolgáltatniuk a NAV számára, jelentősen korlátozták. 
A pénzügyi tevékenységekre vonatkozó IFRS-statisztikákat a társasági adóbevallásban feltüntetett tételeknél ${ }^{11}$ aprólékosabb formában nem szükséges bekérni, mivel azokról a KSH-nak az MNB szolgáltat részletes adatokat.

Az elózőkből adódóan azt a következtetést tudtuk levonni, hogy a költségek és a ráfordítások megjelenítése az IFRS szerint készült pénzügyi kimutatásokban tartalmilag alapvetően azonos az Szt. szerint készült éves beszámolóéval, ám az előbbiek esetén (ahol rendszerint csak egy-egy összefoglaló költség-/ráfordításcsoportot tüntetnek fel) az nagyon összevont. Ezért a KSH úgy döntött, hogy az IFRS szerint beszámoló gazdálkodóegységektől is bekéri kiegészítő információként a kérdőíven korábban szereplő, számviteli analitikában megtalálható költségtételeket. Ez az árbevételnél leírtakhoz hasonlóan szintén nem jelent problémát, mivel ezek az információk a vállalkozások könyvelésében elérhetők.

\subsection{A beruházásstatisztikai adatgyüjtések (OSAP 2237 és 2240) ${ }^{12}$ IFRS-szemléletü elemzése és megállapításai}

Az SBS-nél lényegesen szükebb, ám szintén számviteli információkon alapuló mutatókört használó, STS céljára készült statisztikák, illetve a beruházásstatisztika esetében is viszonylag kisebb kérdőív-módosításokat kellett végrehajtani; elenyészönek mondható azoknak az új információknak a száma, amelyeket be kell kérni a KSH-nak az IFRS-re áttérő vállalkozásoktól. Ennek sok esetben az az oka, hogy a statisztikai, az Szt.- és az IFRS-definíciók elemzése során a szakemberek arra jutottak, hogy az IFRS-tartalom több esetben közelebb áll a közgazdasági és a statisztikai megközelítéshez, mint a magyar számviteli fogalom és tartalom.

Statisztikai értelemben beruházásnak tekintendő a tárgyi eszközök beszerzése, saját vállalkozásban való létesítése, a meglevő tárgyi eszközök bővítése, rendeltetésének megváltoztatása, átalakítása, felújítása, valamint az üzembe helyezésig, a raktárba történő beszállításig felmerült mindazon tevékenységek költsége, amelyek az eszközhöz egyedileg hozzákapcsolhatók. Nem minősülnek beruházásnak az apport keretében átvett tárgyi eszközök és immateriális javak, bérelt vagy lízingszerződés alapján beszerzett tárgyi eszközök, értéktárgyak, karbantartási, javítási költségek.

A beruházási teljesítményérték az egy évnél hosszabb ideig használt eszközök beszerzését vagy azok létesítését foglalja magában, és mint ilyen, egyenlő a tárgyidőszaki ráfordítások összegével, illetve független a pénzügyi teljesítéstől. Ennek megfelelően beruházásként kell elszámolni az engedményekkel csökkentett, felárak-

\footnotetext{
${ }^{11}$ A társasági adóbevallásban szereplő pénzügyi tevékenységi adatok: kapott (járó) osztalék, árfolyamnyereség/-veszteség összevont egyenlege, pénzügyi instrumentumokból származó kamatok és kamatjellegü bevételek, fizetendő kamatok és kamatjellegü ráfordítások, illetve az utóbbiakból a magánszemélyekhez köthető összegek.

${ }^{12}$ OSAP 2237: Negyedéves beruházásstatisztikai jelentés, OSAP 2240: Éves beruházásstatisztikai jelentés.
} 
kal növelt vételárat, amelyet azonban számos tényező (például a szállítási, a rakodási, az alapozási, a szerelési, a próbaüzemelési, az üzembe helyezési, illetve a közvetítői költségek, a bizományi díjak, a beszerzésekhez kapcsolódó adók, a vámköltségek, az előzetesen felszámított, de le nem vonható áfa összege, a raktárba történő beszállításig elszámolt kamat és az üzembe helyezésig felmerült biztositási díj, vagyis minden, üzembe helyezésig [aktiválásig] felmerült ráfordítás) módosít.

Mint azt már említettük, a beruházás statisztikai fogalma és bekerülési értéke sokkal közelebb áll az IFRS-hez, mint a magyar számvitel szerinti beruházás. Ezért a KSH a befektetett eszközökre vonatkozóan is feltárta és minősítette az IFRS és az Szt. közötti különbségeket lehetséges nemzetgazdasági hatásuk szerint, majd ahol szükségesnek vélte, módosította és magyarázta a statisztikai adatszolgáltatást.

A beruházásstatisztikai adatok, hasonlóan a teljesítménystatisztikákhoz, szintén két forrásból származnak. Egyrészt a beruházásstatisztikai jelentések útmutatója meghatározza, hogy az IFRS-t alkalmazó vállalkozásoknak miként kell értelmezniük a beruházás teljesítményértékét: az IFRS szerinti bekerülési értéket növelni kell az állami támogatások összegével, amennyiben az IFRS szerinti bekerülési értékből az levonásra került. ${ }^{13} \mathrm{Az}$ IFRS szerinti bekerülési érték többi része azonos a statisztikai beruházási teljesítménnyel, amelynek sajátos IFRS-elemei az ARO (asset retirement obligation - az eszköz leszerelésének, elszállításának becsült költségei) és a hitelfelvételi költségek minősített eszköz ${ }^{14}$ esetén. ${ }^{15}$ Az útmutató kiemeli, hogy a statisztikai beruházási teljesítményértéknek részét képezhetik a befektetési célú ingatlanokkal, az értékesítésre tartott befektetett eszközökkel és a tulajdonosoknak kiosztásra szánt eszközökkel kapcsolatos beruházások is, amennyiben ezek az eszközök a vállalkozás tevékenységét egy éven túl szolgálják. A KSH a beruházásstatisztikához kapcsolódóan a következö kérdésköröket vitatta meg, értelmezte és szabályozta:

a) Az IFRS az értékcsökkenés elszámolására komponensmegközelítést ${ }^{16}$ alkalmaz, illetve az immateriális javaknál határozott és nem

${ }^{13}$ Az IFRS (az IAS 20. standard) alapján az eszköz finanszírozásához kapcsolódóan kapott állami támogatás két módon számolható el: halasztott bevételként (egyezően a magyar számviteli elöírásokkal) vagy az eszköz bekerülési értékét csökkentő tételként. Az utóbbi esetén van szükség statisztikai kiigazításra.

${ }^{14}$ Az IAS 23. standard szerint a minősített eszköz olyan eszköz, amelynek a használatra vagy értékesítésre kész állapotba hozása szükségszerüen jelentős időt vesz igénybe. Jellemzően ilyen eszközök lehetnek az ingatlanok, a termelö berendezések, a befektetési célú ingatlanok stb.

${ }^{15} \mathrm{Az}$ IFRS szerinti bekerülési érték megegyezik a statisztikai beruházási teljesítménnyel (elemei: vételár, vámok, le nem vonható áfa és egyéb adók, szállítási és kezelési költségek, üzembe helyezési és összeszerelési költségek, szakértői díjak, közvetlenül felmerülő munkavállalói juttatások költsége, a működés tesztelésének költsége [a tesztelés során előállított termékek eladásából származó bevétel nélkül], ARO, hitelfelvételi költségek minősített eszköz esetén stb.).

${ }^{16}$ Az IAS 16. Ingatlanok, gépek, berendezések standard alapján a komponensmegközelítés azt jelenti, hogy egy olyan értékcsökkenthetö eszköznek az értékét, amely hasznos élettartamukat tekintve egymástól lényegesen eltérő elemekre bontható, a különválasztott komponensek szerint, azok hasznos élettartama alapján kell csökkenteni. 
meghatározható hasznos élettartammal rendelkező eszközöket azonosít. Ebből következően az IFRS és az Szt. szerinti értékcsökkenés öszszege eltér egymástól. Annak ellenére, hogy ennek hatása jelentős lehet, statisztikai szinten nem igényel többletadatot, információt, mert az értékcsökkenést a statisztikában modellszámítással határozzák meg és nem a vállalkozások egyedi beszámolói alapján.

b) Az IFRS-ben a forgóeszközök között szerepelnek az ún. értékesítésre tartott befektetett eszközök is, mely kategória az Szt.-ben nem létezik. Ez statisztikai szempontból számottevő hatású lehet. A beruházásstatisztikában az értékesítésre tartott befektetett eszközök tárgyi eszközöknek, beruházásnak minősülnek, ha egy éven túl szolgálják a vállalkozás tevékenységét.

c) Az immateriális javak esetében a két rendszer között a kutatásfejlesztés aktiválási és értékelési szabályaiban van különbség. Ebböl adódóan az immateriális javak bekerülési értéke jelentősen eltérhet az Szt. alapján kimutatott értékhez képest. Mivel az Szt. és az IFRS eltérései e tekintetben olyan sokrétűek, hogy indokolatlan az egymáshoz való „közelítésük”, a KSH a beruházásstatisztikai adatgyüjtések kérdőíveiben a számvitelben aktivált összeg (függetlenül attól, hogy ez Szt.vagy IFRS-alapú) feltüntetését kéri.

d) Az IFRS szerint a pénzügyi lízingszerződés alapján használatba vett tárgyi eszközök értéke az eszközök szerződéskötéskori valós értéke és a fizetendő lízingdíjak jelenértéke közül a kisebb érték. A statisztikában a pénzügyi lízingbe vett eszközök bekerülési értéke az eszközök piaci ára, még akkor is, ha a vállalkozás a fizetendő lízingdíjak jelenértéke alapján számított eszközértéket mutat ki a könyveiben.

e) Az Szt. szerint az alapítás/átszervezés költségei a vállalkozás döntése alapján aktiválhatók. Az IFRS és a statisztika értelmezése ezzel szemben áll, hiszen mindkettőben e költségek az adott időszak eredményét csökkentik, és nem aktiválhatók. Így statisztikai kiigazításra az IFRS-t alkalmazó vállalkozások esetében sincs szükség.

f) Az Szt. és az IFRS szerint beszámoló vállalkozásokra egyaránt vonatkozik, hogy az immateriális javak megszerzését beszerzési, illetve előállítási költségen kell megadniuk, valamint az ásványkincsek feltárása során felmerült összes közvetlen költséget kell kimutatniuk a statisztikai adatszolgáltatás során.

g) A beruházási teljesítményértékben (az Szt. szabályainak megfelelően) a beruházásra fizetett előlegeket el kell számolni, a térítésmentes átadás-átvételt, a tárgyieszköz-apportot, a pénzügyi lízingelt tárgyi eszközöket és az értéktárgyakat viszont nem. 
A beruházásstatisztikai adatokat támasztják alá és részletezik bizonyos szempontok alapján a társasági adóbevallás lapjai. Itt az IFRS szerinti mérleg levezetésében inkább IFRS-sajátosságok azonosíthatók, mint tárgyi eszközök, mivel az ingatlanok, a gépek, a berendezések és a befektetési célú ingatlanok összevontan kerülnek kimutatásra (Társasági adóbevallás A-07-es lap). További statisztikai támogatást nyújt a társasági adóbevallásban az értékcsökkenés és a tárgyi eszközök állományváltozásainak levezetése, mivel ezek kifejezetten statisztikai adatgyüjtés miatt kerülnek be a társasági adóbevallásba.

\section{Az IFRS-statisztikai kérdőívek kitöltési tapasztalatai}

A 2016. január 1-jével IFRS-re átálló vállalatok közül öt került 2016-ban az évközi statisztikai adatszolgáltatói körbe. Ezekböl egy kiemelt nagyvállalat, amelynek súlya nemcsak ágazatában, hanem az egész nemzetgazdaságban is meghatározó. A tárgyidőszakban (2016-ban) a bázisidőszaki (2015. évi) adatokhoz viszonyítva közel azonos tartalommal kérte be a KSH az adatokat, így az áttérés nem okozott törést az évközi teljesítménystatisztikákban. Az Szt. és az IFRS árbevételei között eltérést okozó tételeket (a jövedéki adót és a közvetített szolgáltatások értékét) a statisztika helyesen, jelentős hatásúként kezelte, így a jövedéki adót külön mutatóként figyelte meg, a közvetített szolgáltatások értékét (amely az IFRS szerinti bevételt csökkenti) pedig az árbevétel részeként mutattatta ki a vállalatokkal. Számottevő különbséget okozhat az Szt. és az IFRS árbevétele között az ártámogatások eltérő kimutatása is, a megfigyelt, 2016-ban IFRS-re áttért vállalkozásoknál azonban ilyen tétel nem fordult elö.

Az adatszolgáltatói körbe bevont vállalatok tapasztalatai visszaigazolták, hogy azok számviteli nyilvántartásaiból a kért statisztikai adatok kinyerhetők, a havi teljesítménystatisztikai jelentés kérdőivének útmutatónak megfelelö kitöltése a vállalkozások többsége számára nem okozott nehézséget.

Összevetve 2016 és 2017 első felének összehasonlítható statisztikai adatszolgáltatásait, megállapítható, hogy a vizsgált 111 vállalatból 28 árbevétele nagyobb, 17-é pedig kisebb ütemben nőtt, vagy csökkent az ELÁBÉ (eladott áruk beszerzési értéke) változásához viszonyítva. 66 cégnél, melyek esetén nem az ELÁBÉ, hanem a felhasznált anyagok, igénybe vett szolgáltatások értéke kapcsolható az árbevételhez, az árbevétel 2016 és 2017 első fele között átlagosan 74 százalékkal emelkedett, míg a kapcsolódó költségek körülbelül 2 százalékkal lettek kisebbek.

A termelési érték 64 vállalatnál növekedett, 47-nél pedig csökkent, de összességében 209 milliárd forinttal nőtt. A hozzáadott érték 85 vállalkozásnál emelkedett, 
68 milliárd forintos növekedést eredményezve. Meg kell azonban jegyezni, hogy ezek az értékek nem mutatják meg, mekkora összeg tudható be az IFRS-re való áttérésnek.

Összegzésképpen megállapítható, hogy a vizsgált vállalkozások összteljesítménye javult a különböző mutatók alapján, tehát az IFRS alkalmazása nem járt a nemzeti szintü mutatók értékének romlásával.

\section{Az IFRS bevezetéséhez kötődő, további statisztikai feladatok}

Az SBS-hez felhasznált éves teljesítménystatisztikai adatgyüjtések évközi kérdőíveit lényegesen nagyobb mértékben kellett módosítani más kérdőívekhez képest, ugyanis több pótlólagos adat bekérésére van szükség a nemzetközi és a hazai előírások, adatigények kielégítése érdekében.

Folyamatban van az ESA-hidak újragondolása, szükség szerinti átalakítása és ennek megfelelően a kapcsolódó informatikai rendszerek átállitása is. A GDPszámítások ellenőrzésének standardizálása és megkönnyítése érdekében kialakított egységes táblarendszer (process table) öt nemzetiszámla-kiigazítási kategóriát különböztet meg. Ezek közül az IFRS szempontjából a „fogalmi eltérések” miatt végrehajtandó módosítások lényegesek, amit az ESA 2010 definícióinak való megfelelés érdekében kell elvégezni a számviteli alapadatokon.

Az Szt. értelmében bekért alapadatok korrekciója a nemzeti számlák kimutatásaiban már megtörtént, de az IFRS alkalmazása miatt újra át kell tekinteni, hogy szükség van-e még további kiigazításra.

A termelési oldalról számított GDP szinte minden elemét érintette az áttérés a magyar számviteli beszámolásról az IFRS-re, hiszen a két rendszer között mind az árbevétel, mind a költségek, mind pedig az adók és a támogatások elszámolásánál lényeges különbségek azonosíthatók.

Az Szt. és az IFRS teljesítménystatisztikai eltéréseinek nemzeti számlákra gyakorolt hatásait, értelmezéseit és teljeskörüségét a jövőben tovább kell elemezni. Az ELÁBÉ mérése, kiszürése - ahogy azt korábban bemutattuk - az SBS és az STS esetében is alapvető követelmény, az arra vonatkozó információk bekérése az évközi és az éves teljesítménystatisztikai adatgyüjtéseknél is megtörténik. A termékadók és -támogatások kapcsán ugyanakkor az ESA 2010 olyan részletes korrekciókat ír elő, amelyek csak a szóban forgó adók és támogatások tételes vizsgálatával hajthatók végre. Ismerve azonban a magyar adórendszer szabályozási keretét, nem lehet, és nincs is értelme minden egyes adó és támogatás esetében feltárni, hogy az IFRS-t választó vállalkozások egy-egy adott tételt árbevételként vagy müködési ráfordítás- 
ként számoltak-e el. Ezért a statisztikusok feladata a ,jelentős tételt képviselő” adók és támogatások beazonosítása, majd információk begyüjtése arról, hogy az érintett vállalkozások miként számolták el ezeket pénzügyi kimutatásukban (figyelembe véve, hogy ezeknek az adóknak és a támogatásoknak a nagy részét még a kiegészítő információk között sem részletezik).

\section{Következtetések}

Jelen cikkünkben azt elemeztük, hogy a KSH milyen stratégiai, elméletimódszertani és operatív feladatokkal szembesült az IFRS egyedi pénzügyi beszámolási célra való bevezetése során. A legnagyobb kihívást az IFRS-szabályok megismerése és statisztikai szintủ kezelése jelentette. A cél az volt, hogy a statisztikai adatgyűjtési és -szolgáltatási szabályozás révén a hivatal az IFRS vállalati alkalmazását követően is megbízható statisztikai adatokat nyújtson mind nemzetgazdasági szinten, mind a nemzetközi statisztikák elő́llításához.

Ennek elérése érdekében az egyes számviteli és statisztikai elemeket megjelenítési és értékelési szempontok szerint is meg kellett vizsgálni a teljesítmény- és beruházásstatisztikák esetében. Majd a KSH mérlegelte, hogy jelentős lehet-e az Szt. és az IFRS közötti eltérések nemzetgazdasági szintü statisztikai adatokra gyakorolt hatása, tehát szükséges-e részletező adatok bekérése, a statisztikai jelentések útmutatóinak IFRS szerinti újraértelmezése, valamint a társasági adóbevallás egyes részeinek átalakítása. Az IFRS-hez igazított évközi és éves kérdőívek, illetve a társasági adóbevallás átalakítása csak az első lépés volt a statisztikusok elött álló feladatok sorában, amelyek korántsem zárultak le, hiszen még folyamatban van az IFRS-re áttért cégektől beérkezett adatok kiértékelése és elemzése, melyek a kérdőívek és a kitöltési útmutatók további módszertani jellegü kiigazításait eredményezhetik.

Természetesen néhány vállalat adataiból éppen az IFRS adta rugalmasság, az ágazati specialitások miatt nem lehet, és nem is szabad általános következtetéseket levonni. Azok csak arról adnak visszajelzést a statisztikusok számára, hogy a megkezdett irány alapvetően helyes, és a végrehajtott kiigazítások megfelelő kiindulási alapot biztosítanak, ami azonban az elkövetkező egy-két évben az IFRS-re áttérö vállalkozások számának gyarapodásával felhasználói szempontú finomításra szorulhat.

Elengedhetetlen az IFRS bevezetésének statisztikai mutatókra gyakorolt hatásának mérése. Ezért a KSH-nak - széles körü egyeztetéseket folytatva e kérdésröl a kormányzati, a szabályozó és a felügyeleti szervekkel - olyan eszközöket és módszereket kell alkalmaznia, illetve olyan szakmai megoldásokat kell kidolgoznia, amelyek a mérést lehetővé, a vállalkozások által szolgáltatott, IFRS vagy magyar szám- 
vitel szerinti adatok összegzését pedig értelmezhetővé és megbízhatóvá teszik. Ez a „finomhangolás” csak és kizárólag az adatszolgáltatók, az IFRS-szakértők és a KSH szoros együttműködésével, az adatok egyedi szintủ elemzésével lehetséges.

\section{Irodalom}

AHrendt, B. [2009]: What Are the Costs and Benefits of XBRL in the Financial Services Industry? Master Thesis. Erasmus School of Economics. Rotterdam.

Analysing the use of IFRS Standards. http://www.ifrs.org/use-around-the-world/use-of-ifrsstandards-by-jurisdiction/\#analysis

Az Európai Unió Hivatalos Lapja [2008]: A Bizottság 1126/2008/EK rendelete (2008. november 3.) az 1606/2002/EK európai parlamenti és tanácsi rendelettel összhangban egyes nemzetközi számviteli standardok elfogadásáról (EGT-vonatkozású szöveg). 2008. 11. 29. L 320. 1-433. old.

Bohus G. - MADARASINÉ SZIRMAI A. [2016]: IFRS-ek az egyedi beszámolóban - döntött az Országgyülés. Számviteli Tanácsadó. No. 1. Wolters Kluwer. Budapest. http://ado.hu/szaklap /szamviteli-tanacsado/2016-1-1

Chaidr, A. - Coetsee, D. - Bakker, E. - Varughese, S. - McIlwaine, S. - Fuller, C. - Rands, E. - DE Vos, N. - LONGMORE, S. - Balasubramanian, T. V. [2015]: IFRS 2015: Interpretation and Application of International Financial Reporting Standards. John Wiley \& Sons. New York. https://doi.org/10.1002/9781118889527

Committee on Monetary, Financial and Balance of Payments Statistics [2009], [2011]: International Accounting Standards. $39^{\text {th }}$ Meeting of the Task Force on Accounting and Statistics. 28-29 January. Luxembourg. Progress Report.

Committee on Monetary, Financial and Balance of Payments Statistics [2010]: International Accounting Standards - Completion of the Taxonomy Projects and Possible Way Forward. Working document.

Data Point Model and XBRL. https://eiopa.europa.eu/Pages/Supervision/Insurance/Data-PointModel-and-XBRL.aspx

Dunne, Th. - Helliar, CH. - Lymer, A. - Mousa, R. [2009]: XBRL, the Views of Stakeholders. ACCA Research Report. No. 111. Association of Chartered Certified Accountants. London. http://www.accaglobal.com/content/dam/acca/global/PDF-technical/technologypublications/rr-111-002.pdf

Enria, A. [2012]: Micro-Data for Micro- and Macro-Prudential Purposes. Proceedings of the Sixth ECB (European Central Bank) Conference on Statistics "Central bank statistics as a servant of two separate mandates: price stability and mitigation of systemic risk". ECB. Frankfurt. pp. 136-144. https://www.ecb.europa.eu/pub/pdf/other/centralbankstatistics201207en.pdf ?d86e4f79978605bc110f2fbb576c8bde

Eurostat [2014]: Essential SNA: Building the Basics, 2014 edition. Publications Office of the European Union. Luxembourg. https://doi.org/10.2785/51610

EUROSTAT [2017]: Selected papers from the 2016 Conference of European Statistics Stakeholders. Special Issue. Publications Office of the European Union. Luxembourg. https://doi.org/10.2785/186842 
FÁBIÁN I. [2016]: Konzultáció az alapvető és a felügyeleti adatszolgáltatási MNB rendeletek 2017 re tervezett föbb módositásairól, valamint tájékoztatás az XBRL adatformátum alapjairól és alkalmazásáról. Szeptember 14. Magyar Nemzeti Bank. http://slideplayer.hu/slide/11465923/

HoвBS, D. [2005]: Impacts of International Financial Reporting Standards on business Statistical Data and the National Accounts. Economic Trends. No. 623. October. pp. 42-43.

IFRS Foundation honlapja. www.ifrs.org

IFRS. Eurostat honlapján összegyüjtött 35 dokumentum. http://ec.europa.eu/eurostat/search?p_auth =FYyDzWs4\&p_p_id=estatsearchportlet_WAR_estatsearchportlet\&p_p_lifecycle=1\&p_p_stat e=maximized\&p_p_mode=view\&_estatsearchportlet_WAR_estatsearchportlet_action=search \&text=IFRS

ISTAT (STATistics Italy) - CBS (Statistics Netherlands) - SL (Statistics Lithuania) - ONS (Office For National Statistics) [2011]: Comparison of Business Statistics Characteristics with IAS/IFRS and EU Accounting Directive: the Main Differences Between Statistical and Accounting Concepts and Their Impact on Statistics. ESSnet Admin Data. Work package 7: statistics and accounting standards. https://ec.europa.eu/eurostat/cros/system/files/SGA\%20 2011_Deliverable_7.2.pdf

Kloeden, Ph. [2006]: XBRL Cost-Benefit Analysis: in Theory and Application. Scholar Works. Rochester Institute of Technology. Rochester. http://scholarworks.rit.edu/cgi/viewcontent.cgi? article $=2629 \&$ context $=$ article

LaKatos L. P. - KovÁcs D. P. - Madarasiné Szirmai A. - Mohl G. - RózSA I. [2013]: A Nemzetközi Pénzügyi Beszámolási Standardok elmélete és gyakorlata, 2013. Magyar Könyvvizsgálói Kamara. Budapest.

Madarasiné Szirmai A. - Bartha Á. [2016]: Nemzetközi számviteli ismeretek. Perfekt Kiadó. Budapest.

Magyar Közlöny [2000]: 2000. évi C. törvény a számvitelröl. 95. sz. November 21. 5790-5868. old.

Magyar Közlöny [2014]: 1639/2014. (XI. 14.) Korm. határozat a nemzetközi pénzügyi beszámolási standardok egyedi beszámolási célokra történő hazai alkalmazásáról. 155. sz. November 14. 15322. old.

Magyar Közlöny [2015a]: 1387/2015. (VI. 12.) Korm. határozat a nemzetközi pénzügyi beszámolási standardok egyedi beszámolási célokra történő hazai alkalmazásáról. 80. sz. Június 12. 7408-7409. old.

Magyar Közlöny [2015b]: 2015. évi CLXXVIII. törvény a nemzetközi pénzügyi beszámolási standardok egyedi beszámolási célokra történő hazai alkalmazásának bevezetéséhez kapcsolódó, valamint egyes pénzügyi tárgyú törvények módosításáról. 182. sz. November 26. 2281222836. old.

MohAi Gy. - VÉGH R. [2007]: XBRL az adatfeldolgozás csodaszere? Számvitel, adó könyvvizsgálat. 49. évf. 3. sz. 115-116. old.

Murai B. [2011]: Az éves GDP-számítások keretrendszere. Statisztikai Szemle. 89. évf. 6. sz. 609623. old.

New rules make EU issuers' annual financial reports machine-readable. https://www.esma.europa.eu/press-news/esma-news/new-rules-make-eu-issuers\%E2\%80\%99annual-financial-reports-machine-readable 
ONS (Office for National Statistics) [2013]: Chapter 10 - National Balance Sheet. July. http://webarchive.nationalarchives.gov.uk/20160113185345/http://www.ons.gov.uk/ons/dcp17 1776_318954.pdf

Ten Countries with Open Data. XBRL International. https://www.xbrl.org/the-standard/why/tencountries-with-open-data/

UMENHOFFER F. [2017]: IFRS-alkalmazás az adóhatóság szemszögéböl. Számvitel, adó könyvvizsgálat. 59. évf. 2. sz. 8-10. old.

XBRL International database. www.xbrl.org

\section{Summary}

In Hungary, the IFRS (international financial reporting standards) for individual financial statements are effective from 1 January 2016 (Act CLXXVIII of 2015, hereinafter IFRS Act). The IFRS Act defines the scope and timing of the IFRS application for individual statements, regulates the related audits and accounting tasks and presents the changes in tax and other legislation. The use of the individual IFRS financial statements is optional for some entities and is mandatory for others in the business sectors.

Beyond the IFRS Act, several micro (company-) and macro-level processes are required, which serve the success of the application of IFRS. One of these macro-level tasks is the revision of statistical data supply, for which there are no guidelines in the IFRS Act. Thus, the modification of HCSO (Hungarian Central Statistical Office) questionnaires was rather urgent as the HCSO is one of such organisations that collects data from monthly company reports and from the accounting systems of companies.

The study aims to present how the Hungarian accounting regulations and IFRS were analysed and compared and the way the statistical questionnaires was changed after the IFRS Act came into force and IFRS were started to be used at the national level. The author identifies the most important differences among the two systems and those IFRS rules that are more similar to the statistical approaches than to the Hungarian accounting regulations. In conformity with the IFRS Act and based on international experience, the most important differences are focused on, which can modify the macro-statistical national and international ratios.

Not only findings in accounting are summarized but also those methods (modifications of statistical questionnaires and tax reports) are described that provide solutions for additional data needs due to the application of IFRS. Finally, the experience gained so far in supplying statistical data in IFRS is presented. 